\title{
EFFECTS OF BOARD INDEPENDENCE ON MICROFINANCE INSTITUTIONS' PERFORMANCE: THE CASE OF BANGLADESH
}

\author{
MOHAMMAD DELWAR HUSSAIN ${ }^{1}$ \\ ZUBIR AZHAR ${ }^{2, *}$ \\ IBRAHIM KAMAL ABDUL RAHMAN ${ }^{3}$
}

Received: 10 December 2019 / Revised: 11 May 2020 / Accepted: 14 May 2020

Published online: 12 February 2021

(C) 2021 Faculty of Business and Accountancy, University of Malaya. All rights reserved.

\begin{abstract}
A B S T R A C T
Research aim: This study aims to examine the relationship between board independence and the performance of microfinance institutions (MFIs). Early studies on microfinance have made immense contributions, particularly in identifying the factors that influence performance. However, studies addressing board independence and its impact on performance remain scarce.
\end{abstract}

Design/ Methodology/ Approach: This study utilised a panel dataset involving 80 MFIs in Bangladesh for the period of 2005-2018. A panel data regression technique was applied to measure the relationship between MFIs' performance and board independence based on the 80 cross-sectional MFIs with 13 years of data.

Research findings: Our findings suggest that independent directors and board size facilitate MFIs to become financially sustainable. The findings also indicate that CEO duality enhances institutional sustainability but does not enhance outreach to the poor. While the results of this study partially support the proposition of stewardship theory, the proposition of agency theory is rejected. This indicates that MFIs in Bangladesh are operated by motivated agents with similar interests to the MFIs' owners.

Theoretical contribution/ Originality: This investigation contributes to the microfinance governance literature by highlighting the argument that board independence reduces conflict between MFIs' principle and agent. This study also contributes to the global debate concerning CEO duality and MFIs' double bottom line performance from the perspective of a developing country, such as Bangladesh.

Practitioner/ Policy implication: The practical implication of this research is on governance mechanisms in terms of their effectiveness, which is influenced by MFIs' competence. Since board members should promote stakeholders' interests rather than the interests of the organisation, there is a need for sound guiding principles that should form an integral part of the policy for better MFI governance practices.

Limitation/ Implication: The limitation of this study mainly concerns the lack of evidence concerning whether or not every licensed MFI in Bangladesh has non-manageable stakeholders. Similarly, this study fails to capture the insolvency level of customers. Therefore, future studies may expand on this approach and create a measure for MFIs' outreach to the poor.

Keywords: Bangladesh, Board Independence, Governance, Microfinance

\footnotetext{
${ }^{1}$ School of Business, Green University of Bangladesh (GUB), Dhaka, Bangladesh. ${ }^{2}$ School of Management, Universiti Sains Malaysia, 11800 USM, Penang, Malaysia. ${ }^{3}$ UniKL Business School, Universiti Kuala Lumpur (UniKL), Kuala Lumpur, Malaysia. *e-mail: zubirazhar@usm.edu.my
} 
Type of article: Research paper

JEL Classification: G21, M41

\section{Introduction}

In any business organisation, the board of directors is always regarded as the supreme decision-maker who influences the overall economic activities. However, it has been argued that for business organisations to thrive, the board composition must be appropriately represented. In 2002, Sarbanes-Oxley provided mandatory legislation regarding the representation of outside or independent directors on an organisation's board (Anand, 2012). The reason is that, according to agency theory, the interests of executives or managers may differ from those of shareholders or investors (Christopher, 2010; Donaldson \& Davis, 1991). Therefore, it is imperative that independent directors be appointed to establish and/or maintain effective corporate governance practices within organisations. Board independence occurs when a board member is neither an employee nor an employer of the corporation (Rashid, 2015b). A board member should be free from any business relationship with the corporation and is independent of the executive role (Terjesen et al., 2016). Such characteristics reflect the need for a board of directors that competently provides independent judgement (Ahmad \& Omar, 2016).

There is an argument in the corporate governance literature about the board's competency to monitor management's work or performance (Pugliese et al., 2014; Terjesen et al., 2016; Umor et al., 2020; Zagorchev \& Gao, 2015). This argument is centred around board members' role as agents who are expected to maximise shareholders' wealth (Rashid, 2015a) by appropriately mobilising the machinery arm, which is mainly comprised of managers. As stewardship theory postulates, a manager should be a motivated agent who always works for the betterment of the organisation (Christopher, 2010; Davis et al., 1997; Nasir \& Ali, 2018). In light of the present business landscape characterised by enormous challenges and complexities, it has become apparent that there is a need to reform the board composition with the right talent and skills. Therefore, board reform should not be undermined in light of the continuous urge for board independence, which has been of particular interest in the corporate arena, as highlighted by agency theory (Rashid, 2015b). A similar urge has been echoed by resource dependence theory's advocates in that corporates need to hire skilful board members who can contribute by adding resources to ensure organisational well-being (Drees \& Heugens, 2013). Furthermore, stakeholder theory urges boards to be involved in all kinds of activities of interested parties who have some stake within organisations (Freeman, 2010; Rahman et al., 2019).

While the above notions hold true in the commercial business arena, there is another type of hybrid form of organisations whose ultimate objective is not 
merely seeking profits for survival but also accommodating social outreach (Siti-Nabiha et al., 2019). Such organisations are referred to in this study as microfinance institutions (MFIs). Interestingly, MFIs appear to assume a vital role in advancing the interests of disadvantaged groups of people; hence, MFIs tend to maintain dual missions - to preserve institutional sustainability and to reach out to the poor. Previous studies claimed that there is a mission drift due to a lack of good governance practices (e.g. Halouani \& Boujelbène, 2015; Im \& Sun, 2015; Kar, 2013; Mori \& Mersland, 2014). Studies on governance practices in MFIs have emphasised that governance plays a vital role in the process of decision making, whereby the board of directors is the key party to make business decisions and serve as a whistle-blower within the organisation (Galema et al., 2012; Mersland \& Strøm, 2013; Mori \& Mersland, 2014). However, the existing literature has failed to denote which mechanism is appropriate to ensure board independence in the context of MFIs.

Also, there is a dearth of theoretical knowledge and investigative evidence regarding board independence within the realm of microfinance governance studies (Rahman et al., 2019). Hence, this study attempts to ascertain whether board independence influences MFIs' dual performance in a developing economy and country, namely Bangladesh. As well as being a developing financial market, Bangladesh is the birth country of microfinance. Therefore, there is a need to examine whether board independence significantly affects MFIs' double bottom line performance in Bangladesh. This study is substantially different from the existing literature in two important aspects. First, it extends the existing body of knowledge by considering board independence as an independent variable. Second, it is conducted in a unique setting of agency and stewardship relationships by considering CEO duality and board size as another dimension of the independent variables. Also, it considers the extensive body of multidisciplinary research on the issue of measuring microfinance's dual performance, i.e. institutional sustainability and outreach to the poor. Most of the earlier studies have considered global data or regional datasets and incorporated country control variables. However, organisation age, organisation size, international affiliation, and risk factors need to be considered for a specific country's control factors (Rashid, 2015b; Umor et al., 2020).

This research is expected to contribute to the existing body of knowledge on the role of MFIs' boards by investigating how board independence and other attributes of the board affect the board's ability to protect stakeholders' interests, taking into consideration microfinance's dual mission among the listed MFIs in Bangladesh. The ensuing segments of this article are organised as follows. Section 2 presents an overview of the background of MFIs' board practices in Bangladesh. Previous studies regarding board independence, along with the theoretical underpinnings, are reviewed in Section 3. This section also 
provides hypotheses which are drawn from existing theories. Section 4 presents the methodology adopted in this study with justifications. The empirical results and discussion on the hypothesis tests are discussed in Section 5. Finally, Section 6 concludes by recommending future works in the field of microfinance and outlining some policy implications.

\section{Literature Review}

\subsection{Microfinance Board Practices in Bangladesh}

A general idea of microfinance and corporate board practices in Bangladesh is described in this section. There are mostly management dominated or one-tier board practices in Bangladesh (Rashid, 2015b). This dominating structure is mainly supported by common law practising countries as opposed to civil law practising countries. In this one-tier context, the supervisory board practices are absent, and the non-executive and executive directors discharge their board roles together in a single organisational layer (Rashid, 2015c). This practice is not uncommon in many Anglo-American nation-states, i.e. Australia, the UK, New Zealand, the US, and Canada (Biswas, 2015). The two-tier or monitoring board practices are absent in the microfinance sector (Hasan et al., 2019). Nonetheless, organisations in this sector have a monitoring system through the appointment of outside directors to the board.

MFIs are independent entities with double bottom line objectives, namely, profitability and outreach. In Bangladesh, MFIs practise a hybrid corporate governance system. The MFI concept is relatively new and undergoes continuous improvements. There has been international pressure to reform MFIs' boards, made by international donor organisations such as the World Bank, International Monetary Fund (IMF), and Asian Development Bank (ADB) (Nasir \& Ali, 2018; Uddin \& Choudhury, 2008). Therefore, a corporate watchdog known as the Securities and Exchange Commission Bangladesh (SECB) was established in 1993 (Rashid et al., 2007). This authoritative body administers and enforces the legislation and securities laws under the Securities and Exchange Commission Act 1993. Subsequently, Companies Act 1913 was replaced by Companies Acts 1994, which is also applicable for MFIs (Hasan et al., 2019). Presently, the commercial sector in Bangladesh encompasses a small number of government-owned corporations, joint ventures, and multinational firms, as well as large numbers of privately-owned corporations and MFIs. There tend to be notable institutional differences between developed countries and developing countries such as Bangladesh. One of the fundamental differences is regarding ownership, where companies in developed economies usually appoint professional managers who do not have ownership stakes (Terjesen et al., 2016). Also, the managerial talent within the organisation tends to be diversified. Conversely, the majority of company owners in developing 
economies consist of family members. They tend to have large stakes, giving them ownership control (Rashid, 2015a). Therefore, they have significant control over the corporate board, and this scenario is replicated in the microfinance sector.

Nevertheless, the microfinance sector in Bangladesh is monitored by the central bank, which imposes certain policies on the sector. The governance structure in Bangladesh is a result of a mixture of two control systems, i.e. insider bank-based and outsider market-based (Farooque et al., 2007). Interestingly, the insider bank-based system in Bangladesh is found to be similar to the control model developed in Japan and Germany, and its outsider market-based system is similar to the market model developed in the UK and the US. Such a governance structure has dynamically shaped the reform agendas in Bangladesh's microfinance sector. Biswas (2013) empirically investigated the corporate governance reforms and agency environment in Bangladesh. The reformed corporate governance practices, undertaken in the early 1990s, have provided immense opportunities for more development, particularly in enforcing and monitoring via an internal supervisory body and external regulators (Biswas, 2015; Rashid, 2015a). Therefore, domestic forces and global monetary agencies ought to be equally affected by such reforms. Presently, MFIs' boards in Bangladesh follow traditional practices even though this sector consists of hybrid organisations. Going forward, this sector needs to develop a different, multiple stakeholder-based board approach in order to attain MFIs' dual objectives.

\subsection{Theoretical Discussion and Hypothesis Development}

In the corporate governance literature, there is a vigorous debate on whether the board's independence adds value to the firm (Davis et al., 1997; Rashid, 2015a). The academic world depends extensively on theories, such as economicbased agency theory, management-based stewardship theory, resource dependence theory, and stakeholder theory (Christopher, 2010; Rahman et al., 2019). With some previous studies revealing mixed results, there is a need to conduct more rigorous studies on microfinance governance; hence this study's attempt. Notably, this study considers the proposition based on not only the existing theories but also the empirical findings of some prior studies. Both agency theory and resource dependence theory support the engagement of outside directors who do not have any stake in the organisation (Hideto Dato et al., 2019; Rashid, 2015b). Stakeholder theory supports the same proposition, along with more stakeholder engagement by the corporate board (Freeman, 2010). The theories mentioned above also highlight that board size may affect the decision-making process, either positively or adversely (Hasan et al., 2019).

Meanwhile, stewardship theory claims that the CEO and executive managers are the best stewards of their firm, and hence, there is no need for 
oversight monitoring by outside independent directors (Davis et al., 1997; Rashid, 2015b). This theory argues that since inside directors spend their working lives in the corporation they govern, they understand the business better than do the outside directors and hence can make superior decisions. Thus, this study needs to incorporate a three-dimensional discussion based on multi-theoretical propositions for the hypothesis development, i.e. independent directors on the board, board size, and CEO duality.

It is not uncommon that the board members are the main persons responsible for maintaining an internal governance system that helps resolve issues between principals and agents. The board of director's motivations would be adjusted according to the interests of the principals, as the board would be held accountable for failing to perform effective monitoring (Bassem, 2009; Hartarska, 2005; Hartarska \& Mersland, 2012). Moreover, the board of directors deals with its own reputation and is collateral for the general population. In this regard, the board's image is factored against the percentage of outside or independent directors (Balachandran \& Faff, 2015; Balc et al., 2013; Bauer et al., 2008; Organisation for Economic Co-operation and Development [OECD], 2015; Stein, 2008; Uddin \& Choudhury, 2008). Independent directors should not be employees of the organisation and should have no relationship with the organisation, and they are expected to act as informants to the organisation (Biswas, 2015; Rashid, 2015b). Previous research has found mixed results about the effects of independent directors on MFIs' performance. Conversely, in the banking literature, it is found that a larger percentage of outside or independent directors has a significant positive effect on banks' performance (Das \& Ghosh, 2004; Lai \& Choi, 2014; Akingunola et al., 2013). Unlike for-profit boards, non-profit boards naturally consist of outsiders (Hartarska, 2005; Hartarska \& Mersland, 2012). Despite this difference, academic scholars advocating the agency perspectives have urged for mandatory independent directors' participation on the board (Bassem, 2009; Hartarska et al., 2013). This proposition is based on a belief that non-executive or independent (outside) directors provide more benefits to MFIs' boards in Bangladesh. Hence, this study hypothesises that:

$H_{1}$ : The participation of independent directors on the board has a significant effect on the double bottom line performance of MFIs in Bangladesh.

The efficacy of the board is also influenced by the number of board members or panel size. Nonetheless, the impact of board size on the performance of MFIs is not clear. There may be a perspective that a bigger board is preferred for corporate execution since the board members bring a range of expertise that will help achieve preferred decisions and make it harder for a powerful CEO to dominate (Bassem, 2009; Hartarska, 2005). Investigations on non-profit boards 
suggest that a bigger board might be useful due to the extra obligations that the board has in directing fundraising, but there is no experimental backing to this claim (Hartarska \& Mersland, 2012). Instead, as stated by the agency-based theory, the larger the board, the more wasteful or inefficient it is (Mori \& Mersland, 2014). Moreover, bigger boards tend to be less effective than smaller boards because when these boards are excessively big, the situation may lead to free-riding by some executives. Previous studies regarding microfinance governance did not find any consistent evidence. Few studies found a positive relationship between larger boards and MFIs' performance (Bassem, 2009; Mersland \& Strøm, 2009a, 2009b), while some other studies identified a weak negative relationship between bigger boards and MFIs' dual missions (Hartarska \& Mersland, 2012; Mersland \& Strøm, 2013). Scholars also claim that MFIs' effectiveness will increase if board size is increased up to nine members; then, any further increase in board size will reduce MFIs' effectiveness (Hartarska \& Mersland, 2012). Considering these issues, this study utilises a measure that captures institutional sustainability and outreach concurrently and proposes the following hypothesis:

$\mathrm{H}_{2}$ : Board size has a significant effect on the double bottom line performance of MFIs in Bangladesh.

The board of directors is the key role players in an organisation. The person who chairs the board is significant for the organisational decision-making system. The CEO manages the corporation and sometimes acts as the chairperson on the board (Zabri et al., 2016). Agency theory proposes that the board chairman and the CEO should be different persons (Dey, 2008; Eisenhardt, 1989; Jensen \& Meckling, 1976; Rost et al., 2010). Conversely, stewardship theory supports the notion that the chairman and the CEO should be the same person (Davis et al., 1997; Donaldson, 1990; Donaldson \& Davis, 1991). Thus, this study refers to the situation where a person simultaneously assumes the roles of the CEO and the chairman of the board as CEO duality. Agency theory postulates that CEO duality tends to give the CEO enormous power, which may jeopardise an organisation's internal control system (Rashid, 2015b). Given that the CEO has a significant influence on the board's functions, there is a need for the board to exercise effective monitoring, which depends on the distribution of power between the chairperson of the board and the CEO (Hussain et al., 2019; Krause et al., 2014). Such distribution of power is important to restore good governance, as CEO duality makes it difficult for the board to remove poorly performing managers (Drees \& Heugens, 2013). CEO duality may also impair independent or outside directors' ability to bring independent advice and judgement to the board (Christopher, 2010; Rahman et al., 2019). Generally, previous studies have recognised CEO duality as an 
important variable as it has been the main highlight in the stewardship-agency perspective (Balachandran \& Faff, 2015; Brennan \& Solomon, 2008; Chen \& Huang, 2014; Cheung et al., 2011; Jones, 2008; Zabri et al., 2016). The perspective is deemed relevant to be extended to MFIs given that they are run by NGOs, which often appoint the board chairman as the organisation's CEO. Microfinance practitioners claim that CEO duality has a significant impact on serving clients and portfolio yields (Hideto Dato et al., 2019). Therefore, this study has developed the following hypothesis:

$H_{3}$ : CEO duality has a significant effect on the double bottom line performance of MFIs in Bangladesh.

\section{Methodology}

\subsection{Sampling}

This study has applied a quantitative technique based on panel data derived from annual financial reports, organisations' website information, selfconducted surveys over the telephone or e-mail, and reports of the World Bankhosted organisation, Consultative Group to Assist the Poor (CGAP) using the mixed-market database.

This study focuses on MFIs in Bangladesh as a representative of frontier economic markets or developing countries. There are thousands of MFIs in Bangladesh (Ahmed, 2009; Quayes \& Khalily, 2013), and most of them are run by NGOs, banks, non-banking financial institutions, cooperative societies, foundations, development organisations, and others. According to the Microcredit Regulatory Authority (MRA) of Bangladesh, there was a total of 724 NGO-MFIs holding government licenses as of June 2019. Grameen Bank has been operating under the Central Bank's amendment ordinance since 1983. Besides, there are large numbers of cooperative societies providing microcredit services without holding government licenses. This study found the absence of a dedicated database in Bangladesh that could provide data on the governance and performance of MFIs.

For the sample selection, this study had set the criterion that the MFIs should have been operating for more than a decade. The reason is that new MFIs do not have a sufficient timeframe to offer significant information about governance practices. Besides, new enterprises tend to have solvency issues as they focus on developing the business. This study also expected the MFIs with more than one decade of loaning experiences to have had more time actualising all corporate governance practices and executing their financial transactions and decisions (Brennan \& Solomon, 2008). Therefore, recently established MFIs were excluded from the sample. 
Past studies have accentuated that organisation size is important for good corporate governance practices (Hartarska, 2005; Kyereboah-Coleman \& Osei, 2008; Mersland \& Strøm, 2013). The supposition is that MFIs with a capital of $\$ 100$ million or greater would be less averse to embrace the governance frameworks than enterprises with small capital. In this regard, agency-related issues may arise in small enterprises due to the owners' inability to legitimately and properly monitor the corporate executives. Therefore, the good corporate governance components of large enterprises may reduce the possibility of agency conflicts.

This study relied on MFIs' board independence and performance-related data, such as whether they have the information inputs on operational selfsufficiency (OSS), financial self-sufficiency (FSS), return on assets (ROA), breadth, and depth. In summary, the study sample has to meet the following three criteria: (i) at least one decade of microfinance experience with corporate governance practices (Beisland et al., 2015); (ii) has a capital of at least $\$ 100$ million (Creswell, 2013; Lee, 2009); and (iii) has OSS, FSS, ROA, breadth, and depth data inputs. This study identified 80 MFIs in Bangladesh that met these specified criteria. The MFIs also report directly to the CGAP. These 80 MFIs are dispersed in various localities in Bangladesh in both rural and urban areas. MFIs' performance in terms of rural and urban areas are also rationalised in this study. Therefore, the unit of analysis for this study is 80 Bangladeshi MFIs.

\subsection{Variable Selection and Measurement}

\subsubsection{Dependent Variables: Microfinance Performance}

It is well recognised that in any business organisation, managers are vested with the power to make business decisions on behalf of the stakeholders. The prime aim of establishing such a structure is to ensure organisational sustainability, achieved through excellent performance. Nevertheless, in the case of microfinancing, a difference structure should be expected. Given that microfinance works for dual missions, i.e. institutional sustainability and outreach to the poor, the performance aspect might receive different treatment. Following a review of several previous studies, it has become apparent that there is a need to develop different sets of performance indicators to cater to the dual missions. In other words, it is necessary to assess MFIs' operational, financial, and return on assets in order to determine their profitability performance (Bassem, 2009; Beisland et al., 2015; Mori \& Mersland, 2014). Meanwhile, outreach to the poor is measured based on breadth and depth (Bassem, 2009; Hartarska, 2005; Im \& Sun, 2015; Mersland \& Strøm, 2009a). To achieve the objectives of this study, the two performance criteria of MFIs are treated as the dependent variables. The profitability performance is represented by operational self-sufficiency (OSS), financial self-sufficiency 
(FSS), and return on assets (ROA). Meanwhile, outreach to the poor is represented by breadth (the present status of the borrowers) and depth (the loans provided to poorer borrowers). The measurements of these dependent variables are presented in Table 1.

Table 1: The dependent variables and measurement

\begin{tabular}{|c|c|c|}
\hline Variables & Symbol & Measurement \\
\hline \multicolumn{3}{|c|}{ Institutional Sustainability } \\
\hline $\begin{array}{l}\text { Operational } \\
\text { self- } \\
\text { sufficiency }\end{array}$ & OSS & $\begin{array}{l}\text { Operating revenue/(financial expense + loan loss provision } \\
+ \text { operating expense). It shows that an MFI how well cover } \\
\text { its expenditures through operative income. Expressed as a } \\
\text { percentage, it reflects the ability to cover the expenses with } \\
\text { the revenues generated (Bassem, 2009; Hartarska, 2005). }\end{array}$ \\
\hline $\begin{array}{l}\text { Financial } \\
\text { self- } \\
\text { sufficiency }\end{array}$ & FSS & $\begin{array}{l}\text { Adjusted operating revenue/Adjusted (financial expense }+ \\
\text { loan loss provision expense }+ \text { operating expense). It shows } \\
\text { in which degree the operating income recovers operating } \\
\text { expenses after the adjustments. The expenses include all } \\
\text { kinds of operating expenses which are already measures in } \\
\text { OSS along with the value of subsidies and cost of inflation } \\
\text { (Cull et al., 2009, 2011, 2014). }\end{array}$ \\
\hline $\begin{array}{l}\text { Return on } \\
\text { Assets }\end{array}$ & ROA & $\begin{array}{l}\text { Return on Assets = Net Income/Total Assets. ROA } \\
\text { displayed as percentage form. It indicates how an MFI } \\
\text { becomes profitable in terms of total assets. It gives a clear } \\
\text { idea to investors, managers, analyst and the stakeholders } \\
\text { about how MFIs utilized its assets to generate earnings } \\
\text { (Hartarska, 2005; Mersland \& Strøm, 2009a). }\end{array}$ \\
\hline \multicolumn{3}{|c|}{ Outreach to the Poor } \\
\hline $\begin{array}{l}\text { Breadth of } \\
\text { Outreach }\end{array}$ & Breadth & $\begin{array}{l}\text { The number of current active clients or borrowers. It is } \\
\text { representing that an MFI arrests its existing clients or the } \\
\text { loan receivers currently functioning (Im \& Sun, 2015; Mori \& } \\
\text { Mersland, 2014). }\end{array}$ \\
\hline $\begin{array}{l}\text { Depth of } \\
\text { Outreach }\end{array}$ & Depth & $\begin{array}{l}\text { A number of active clients or breadth/GDP per capita. It is a } \\
\text { socioeconomic factor, the higher values show MFI attends } \\
\text { on wealthier borrowers (Bassem, 2009; Hartarska, 2005; Im \& } \\
\text { Sun, 2015; Mersland \& Strøm, 2009a). }\end{array}$ \\
\hline
\end{tabular}

\subsubsection{Independent Variables: Board Independence}

Based on multi-theoretical approaches, this study developed three independent variables that influence the two-fold performance of the microfinance boards in Bangladesh, as shown in Table 2.

\subsubsection{Control Variables}

The control variables in this study are regarded as experimental components. They are unchanged or constant during the course of examination (Rashid, 2015b). These variables also influence tentative results or empirical findings, 
and they are held constant while investigating the relationships between the dependent and independent variables (Rashid, 2013). Apart from age and size, this study includes international connection, portfolio risk, and risk coverage as the control variables. International connection has some effects on governance mechanisms (Copestake et al., 2016). Also, the risk factors may vary across organisations and have significant effects on MFIs' double bottom line performance (Devi \& Shaikh, 2017). Table 3 below shows the measurement and explanation of the control variables.

Table 2: The independent variables and measurement

\begin{tabular}{lll}
\hline Variables & \multicolumn{1}{c}{ Symbol } & Measurement \\
\hline \multicolumn{2}{l}{ The Independent Variables } & \\
\hline $\begin{array}{l}\text { Independent } \\
\text { Directors }\end{array}$ & IndD & $\begin{array}{l}\text { The percentage of the board of directors with whom the } \\
\text { MFIs do not have any kind of relationship or affiliation } \\
\text { (Christopher, 2010; Davis, 2005; Freeman, 2010). }\end{array}$ \\
Board size & BS & $\begin{array}{l}\text { A total number of board members (Chen \& Huang, 2014; } \\
\text { Zagorchev \& Gao, 2015). } \\
\text { A dummy variable, whereas used 1 if CEO and Chairman } \\
\text { is a similar person or zero otherwise (Hartarska, 2005; } \\
\text { Mersland \& Strøm, 2009a). }\end{array}$ \\
\hline
\end{tabular}

Table 3: The control variables and measuremen

\begin{tabular}{|c|c|c|}
\hline Variables & Symbol & Measurement \\
\hline \multicolumn{3}{|c|}{ The Control Variables } \\
\hline MFI age & Age & MFI's experience since its inception (Rashid, 2015a). \\
\hline MFI size & Size & $\begin{array}{l}\text { MFI's total assets grounded on accounting data (Rashid, 2013, } \\
\text { 2015a). }\end{array}$ \\
\hline $\begin{array}{l}\text { International } \\
\text { connection }\end{array}$ & In.Con. & $\begin{array}{l}\text { Used dummy that equals ' } 1 \text { ' if the MFI has international } \\
\text { affiliation and zero otherwise (Hossain, 2013). }\end{array}$ \\
\hline $\begin{array}{l}\text { Portfolio at } \\
\text { Risk }\end{array}$ & Po.Risk & $\begin{array}{l}\text { Outstanding balance at } 30 \text { days }+ \text { renegotiated } \\
\text { portfolio/Adjusted Gross Loan Portfolio (Balachandran \& } \\
\text { Faff, 2015; Schneider \& Scherer, 2015). }\end{array}$ \\
\hline Risk Coverage & Risk.Co & $\begin{array}{l}\text { Loan Loss Allowance/Portfolio at Risk (Balachandran \& Faff, } \\
\text { 2015; Schneider \& Scherer, 2015). }\end{array}$ \\
\hline
\end{tabular}

\subsection{Techniques of Data Analysis}

This research applied quantitative techniques to identify the relationship between board independence and microfinance performance in Bangladesh. Initially, simple descriptive statistical tests such as mean, standard deviation, dispersion of variables, skewness and kurtosis were carried out for all the variables to determine their suitability for multivariate analysis (Creswell, 2013; Wooldridge, 2010). Based on the descriptive analysis and covariance tables, this study found no major problem for further diagnosis through inferential analysis. In the same way, this study utilised a panel data regression technique 
to quantify the relationship between MFIs' performance and board independence, based on the previous studies (see Hartarska, 2005; KyereboahColeman \& Osei, 2008; Mersland \& Strøm, 2013). The sample size of this study is 80 MFIs in Bangladesh with 13 years of data each, resulting in a total of 1,040 observations.

The double bottom line performance is represented by institutional sustainability and outreach to the poor for firm $i$ during the fiscal year $t$. The cross-sectional variation of board independence could be affected by idiosyncratic MFIs' characteristics. Thus, this study controlled other variables that could impact MFIs' performance, namely MFIs' age, size, international affiliation, portfolio at risk, and risk coverage ratios. This method could be regarded as having a long-run orientation. The dependent variables of this study are components of microfinance performance, consisting of MFIs' profitability and outreach performance. Board independence is expected to have a positive impact on MFIs' performance. The regression function used in this study is MFIs' performance $=f$ (independent directors, board size, CEO duality, MFIs' age, MFIs' size, international affiliation, portfolio at risk, and risk coverage).

There are various options of panel data regression techniques, such as pooled (ordinary least squares or OLS), fixed effects (least square dummy variable or LSDV), random effects (generalised least squares or GLS), two-stage least squares (2SLS), and dynamic panel (Greene, 2003; Gujarati, 2004; Kyereboah-Coleman \& Osei, 2008). Given the many options available, this study had to choose the most appropriate model. In finalising the model selection, this study applied each model separately and found mixed outcomes along with analytical problems. Considering the alternative approaches for testing the hypotheses, this study followed the recommendations of Breitung and Das (2005). From the regression results, it turned out that the robust OLS $t$ statistic performed well in comparison to other models. The reason is attributed to two common types of problem in the panel dataset: heteroskedasticity for cross-sectional data and serial correlation for time series data (Baltagi, 2008; Greene, 2003; Gujarati, 2004). This study also applied further diagnostic checks, namely modified Wald test and Wooldridge test to check the heteroskedasticity and auto-correlation problems. Finally, the results identified no such type of problem in the dataset. The econometrics modelling of the panel dataset is written as:

$$
y_{i, t}=\alpha+\beta^{\prime} x_{i, t}+\mu_{i, t}
$$

where $i=1 \ldots, N ; t=1 \ldots, T$; and $X_{i, t}$ is a $K$-dimensional vector of explanatory variables not including the constant, while $\mu_{i, t}$ is the error term. In estimating 
the panel data model, this study considers the behaviour of the components of disturbance, $\mu_{i, t}$. The error term in the regression model consists of two components: a time-invariant individual effect and a remaining white noise error term. In this specification, the disturbance term, $\mu_{i, t}$, is further decomposed. Hence:

$$
\mu_{i, t}=\mu_{i}+v_{i, t}
$$

where $\mu_{i}$ denotes the unobservable individual-specific effect and $\mu_{i, t}$ denotes the remainder disturbance. $\mu_{i}$ is time-invariant and essentially accounts for any unobserved effect that is not captured in the specification. On the other hand, $\mu_{i, t}$ varies with both the cross-sectional variables and time and could even be considered as the usual disturbance in the regression.

The following equations describe the regression models, which are estimated separately for each measure of performance:

Equation 1:

$O S S_{i, t}=\alpha+\beta_{1}^{\prime} \operatorname{InD}_{i, t}+\beta_{2}^{\prime} B S_{i, t}+\beta_{3}^{\prime} C E O D u_{i, t}+\beta_{4}^{\prime} A g e_{i, t}+\beta_{5}^{\prime} \operatorname{Size}_{i, t}+\beta_{6}^{\prime} \operatorname{In} A_{i, t}+\beta_{7}^{\prime} P R_{i, t}+\beta_{8}^{\prime} R C_{i, t}+\mu_{i, t}$

Equation 2:

$F S_{i, t}=\alpha+\beta_{1}^{\prime} I n D_{i, t}+\beta_{2}^{\prime} B S_{i, t}+\beta_{3}^{\prime} C E O D u_{i, t}+\beta_{4}^{\prime} A g e_{i, t}+\beta_{5}^{\prime} \operatorname{Size}_{i, t}+\beta_{6}^{\prime} \operatorname{InA}_{i, t}+\beta_{7}^{\prime} P R_{i, t}+\beta_{8}^{\prime} R C_{i, t}+\mu_{i, t}$

Equation 3:

$R O A_{i, t}=\alpha+\beta_{1}^{\prime} \operatorname{InD}_{i, t}+\beta_{2}^{\prime} B S_{i, t}+\beta_{3}^{\prime} C E O D u_{i, t}+\beta_{4}^{\prime} A g e_{i, t}+\beta_{5}^{\prime} \operatorname{Size}_{i, t}+\beta_{6}^{\prime} \operatorname{In} A_{i, t}+\beta_{7}^{\prime} P R_{i, t}+\beta_{8}^{\prime} R C_{i, t}+\mu_{i, t}$

Equation 4:

Breadth $_{, t}=\alpha+\beta_{1}^{\prime} I n D_{i, t}+\beta_{2}^{\prime} B S_{i, t}+\beta_{3}^{\prime} C E O D u_{i, t}+\beta_{4}^{\prime}$ Age $_{i, t}+\beta_{5}^{\prime}$ Size $_{i, t}+\beta_{6}^{\prime} I n A_{i, t}+\beta_{7}^{\prime} P R_{i, t}+\beta_{8}^{\prime} R C_{i, t}+\mu_{i, t}$

Equation 5:

Depth $_{i, t}=\alpha+\beta_{1}^{\prime} \operatorname{InD}_{i, t}+\beta_{2}^{\prime} B S_{i, t}+\beta_{3}^{\prime} C E O D u_{i, t}+\beta_{4}^{\prime} A g e_{i, t}+\beta_{5}^{\prime} \operatorname{Size}_{i, t}+\beta_{6}^{\prime} \operatorname{In}_{i, t}+\beta_{7}^{\prime} P R_{i, t}+\beta_{8}^{\prime} R C_{i, t}+\mu_{i, t}$

where $i=1 \ldots, 80$ MFIs and $t=1 \ldots, 13$ years. OSS, FSS, and ROA represent operational self-sufficiency, financial self-sufficiency, and return on assets, respectively, for MFIs' sustainability. Breadth and Depth represent outreach to the poor for the MFIs in Bangladesh. Meanwhile, $I n D, B S$, and CEODu are vectors of the board independence variables, namely independent directors, board size, and CEO duality, respectively. Age, Size, InA, $P R$, and $R C$ are vectors of the control variables, namely MFIs' age, MFIs' size, international affiliation, 
portfolio at risk, and risk coverage. Finally, $\mu_{i, t}$ represents the disturbance term for the study.

\section{Findings and Discussion}

Table 4 reports this study's descriptive statistics, consisting of the mean, median, standard deviation, dispersion of the variables, skewness, and kurtosis. The average values of OSS, FSS, and ROA for institutional sustainability are $131 \%, 121 \%$, and $4.31 \%$, respectively. The standard deviation values of OSS, FSS, and ROA are $0.381,0.353$, and 0.095 , respectively. In every case, the data is positive or right-skewed, but the kurtosis value exceeds 3 . This finding implies that on average, the MFIs in Bangladesh are operationally and financially self-sufficient, albeit the return on asset is not at a satisfactory level. Conversely, the average breadth and depth of outreach to the poor are 4.61 and 0.19, respectively, suggesting that the MFIs in Bangladesh are providing loans to economically privileged individuals. Consequently, this study recognises the existence of a mission drift in the context of developing countries. This study's result is similar to the findings reported by Hasan et al. (2019), Mersland and Strøm (2014), and Mia and Chandran (2016).

Independent director representation on the board is about $48 \%$ on average and ranges from $30 \%$ to $71.4 \%$. Only $9 \%$ of the CEOs also assume the role of the board chairman. The average board size is eight persons, consistent with Hartarska and Mersland's (2012) recommendation to maintain a maximum of eight or nine board members for a better-performing MFI. The average length of experience of MFIs in providing microfinance services in Bangladesh is about 26.67 years, and the average asset size is BDT5.97 million. The average values for MFIs' international affiliation, portfolio at risk, and risk coverage ratio are $0.563,0.063$, and 1.284 , respectively. In every case, the data is positive or rightskewed, except for CEO duality and international affiliation. However, the kurtosis value is leptokurtic in every case except for independent director, MFIs' age, and international affiliation. Considering these values, it is clear that the dataset has a dispersion problem. Therefore, this study needs to consider a more robust analysis for the panel data regression model (Greene, 2003; Wooldridge, 2010).

Table 5 explains the correlation conditions for the independent variables, which suggest that there is no significantly strong correlation among the explanatory variables. It is a prerequisite that the variables meet the conditions for multicollinearity. Multicollinearity refers to a condition where the independent or explanatory variables are significantly correlated with one another (Rashid, 2015a). When high degrees of correlation are found among the independent variables, the affected variables must be eliminated. Table 5 indicates that there is no strong correlation among the explanatory variables, as 
all the coefficient values are below 0.57. Therefore, there is no serious multicollinearity problem among the independent variables.

Table 4: Descriptive statistics

\begin{tabular}{|c|c|c|c|c|c|c|}
\hline & Mean & Std.D. & Min. & Max. & Skewness & Kurtosis \\
\hline $\begin{array}{l}\text { Operational } \\
\text { self- } \\
\text { sufficiency } \\
\text { (OSS) }\end{array}$ & 1.314 & 0.381 & 0.346 & 2.984 & 1.265 & 5.423 \\
\hline $\begin{array}{l}\text { Financial } \\
\text { self- } \\
\text { sufficiency } \\
\text { (FSS) }\end{array}$ & 1.216 & 0.353 & 0.320 & 2.760 & 1.265 & 5.423 \\
\hline $\begin{array}{l}\text { Return on } \\
\text { Assets (ROA) }\end{array}$ & 0.043 & 0.095 & -0.792 & 0.895 & 1.730 & 32.717 \\
\hline Breadth & 4.613 & 0.779 & 2.699 & 6.903 & 0.335 & 4.087 \\
\hline Depth & 0.193 & 0.103 & 0.056 & 0.968 & 5.208 & 38.427 \\
\hline $\begin{array}{l}\text { Independent } \\
\text { Director }\end{array}$ & 0.486 & 0.089 & 0.300 & 0.714 & 0.450 & 2.811 \\
\hline Board size & 8.023 & 1.436 & 7 & 13 & 1.625 & 5.531 \\
\hline CEO Duality & 0.909 & 0.287 & 0 & 1 & -2.857 & 9.163 \\
\hline MFI's Age & 26.697 & 8.781 & 4 & 51 & 0.209 & 2.443 \\
\hline $\begin{array}{l}\text { MFI's Size } \\
(\log )\end{array}$ & 5.970 & 2.530 & 4.714 & 9.414 & 0.661 & 3.495 \\
\hline $\begin{array}{l}\text { International } \\
\text { Affiliation }\end{array}$ & 0.563 & 0.838 & 0 & 1 & -0.256 & 1.065 \\
\hline $\begin{array}{l}\text { Portfolio at } \\
\text { Risk }\end{array}$ & 0.063 & 0.496 & -0.019 & 0.477 & 2.213 & 9.052 \\
\hline $\begin{array}{l}\text { Risk } \\
\text { Coverage }\end{array}$ & 1.284 & 0.064 & -0.004 & 11.889 & 3.358 & 19.405 \\
\hline
\end{tabular}

Table 5: Correlation matrix of the independent variables

\begin{tabular}{lllllllll}
\hline & InD & BS & CEOD $\boldsymbol{u}$ & Age & Size & InA & Po.Risk & Risk.Cov \\
\hline InD & 1.00 & & & & & & & \\
BS & -0.33 & 1.00 & & & & & & \\
CEODu & 0.13 & -0.02 & 1.00 & & & & & \\
Age & -0.09 & 0.14 & 0.05 & 1.00 & & & & \\
Size & -0.03 & 0.31 & 0.06 & 0.21 & 1.00 & & & \\
InA & -0.08 & 0.26 & 0.12 & 0.36 & 0.57 & 1.00 & & \\
Po.Risk & -0.07 & 0.09 & -0.07 & 0.25 & 0.19 & 0.39 & 1.00 & \\
Risk.Cov & -0.15 & 0.11 & 0.02 & 0.20 & -0.02 & 0.02 & 0.08 & 1.00 \\
\hline
\end{tabular}

Table 6 below demonstrates the relationship between board independence and MFI's double bottom line performance in Bangladesh. The results are presented with the eight predictor variables: independent director, board size, CEO duality, MFIs' age, MFIs' size, international affiliation, portfolio risk, and risk coverage. This study also has five dependent variables, namely, 
operational self-sufficiency (OSS), financial self-sufficiency (FSS), return on assets (ROA), breadth of outreach, and depth of outreach. While OSS, FSS, and ROA are regarded as the predictors of institutional sustainability performance, the breadth and depth of outreach are the predictors of outreach performance. These predictors are shown at the top of Table 6 as equations 1-5, whereas the explanatory variables are presented in the table's vertical axis.

Table 6: Relationship between Board Independence and MFIs' performance in Bangladesh

\begin{tabular}{llllll}
\hline & Equation 1 & Equation 2 & Equation 3 & Equation 4 & Equation 5 \\
\hline Variables & OSS & FSS & ROA & Breadth & Depth \\
Independent & $0.365^{* * *}$ & $0.337^{* * *}$ & 0.004 & 0.069 & -0.008 \\
Director & $(2.66)$ & $(2.66)$ & $(0.12)$ & $(0.55)$ & $(-0.20)$ \\
Board Size & $0.063^{* * *}$ & $0.058^{* * *}$ & 0.001 & $-0.038^{* * *}$ & 0.0002 \\
& $(6.95)$ & $(6.95)$ & $(0.65)$ & $(-4.67)$ & $(0.10)$ \\
CEO Duality & $0 . .102^{* * *}$ & $0.094^{* * *}$ & $0.032^{* * *}$ & $-0.133^{* * *}$ & $-0.071^{* * *}$ \\
& $(2.51)$ & $(2.51)$ & $(3.13)$ & $(-3.60)$ & $(-6.39)$ \\
MFIs Age & $0 . .009^{* * *}$ & $0.0085^{* * *}$ & $0.002^{* * *}$ & $0.004^{* * *}$ & .00006 \\
& $(6.45)$ & $(6.45)$ & $(5.53)$ & $(2.82)$ & $(0.16)$ \\
MFIs Size & $-0.082^{* * *}$ & $-0.076^{* * *}$ & $-0.015^{* * *}$ & $0.807^{* * *}$ & $-0.019^{* * *}$ \\
& $(-4.45)$ & $(-4.45)$ & $(-3.11)$ & $(47.80)$ & $(-3.90)$ \\
International & $-0.065^{* * *}$ & $-0.061^{* * *}$ & $-0.022^{* * *}$ & $0.046^{* * *}$ & $0.012^{* *}$ \\
Affiliation & $(2.57)$ & $(-2.57)$ & $(-3.35)$ & $(2.01)$ & $(1.67)$ \\
Portfolio Risk & $-0.625^{* * *}$ & $-0.578^{* * *}$ & $-0.263^{* * *}$ & $0.429^{* * *}$ & $-0.272^{* * *}$ \\
& $(-3.21)$ & $(-3.21)$ & $(-5.31)$ & $(2.41)$ & $(-5.15)$ \\
Risk Coverage & $-0.032^{* * *}$ & $-0.029^{* * *}$ & -0.0009 & $0.019^{* * *}$ & $-0.011^{* * *}$ \\
& $(-3.28)$ & $(-3.28)$ & $(-0.37)$ & $(2.12)$ & $(-4.36)$ \\
\hline Constant & $0.967^{* * *}$ & $0.894^{* * *}$ & $0.074^{* *}$ & $-0.606^{* * *}$ & $0.416^{* * *}$ \\
& $(6.15)$ & $(6.15)$ & $(1.86)$ & $(-4.23)$ & $(9.77)$ \\
Observations & 1040 & 1040 & 1040 & 1040 & 1040 \\
Adj R-squared & 0.0924 & 0.0924 & 0.0653 & 0.8193 & 0.0836 \\
Prob $>$ F & 0.0000 & 0.0000 & 0.0000 & 0.0000 & 0.0000 \\
F (9, 1030) & 12.75 & 12.75 & 9.06 & 524.39 & 11.54 \\
\hline
\end{tabular}

From the above regression table, this study identifies a significant positive relationship between independent directors' participation on the board and MFIs' operational and financial self-sufficiency in Bangladesh. However, the independent director variable has no relationship with the return on assets and the breadth of outreach, whereas its relationship with the depth of outreach is negative. Grounded on the existing literature, the preliminary analysis suggests that independent directors' participation on the board might have a positive effect on MFIs' performance (Bassem, 2009; Benedetta et al., 2015; Hartarska, 2005; Hartarska \& Mersland, 2012; Kar, 2012; Kyereboah-Coleman \& Osei, 2008; Mersland \& Strøm, 2009a). This result is consistent with agency and resource dependence theories (Freeman \& Evan, 1990; Hill \& Jones, 1992; Jensen \& Meckling, 1976; Pfeffer \& Salancik, 2003; Sundaram \& Inkpen, 2004). These 
theories recognise that independent directors have valuable resources, such as objectivity and technical expertise gained from their knowledge and business experience. With their strong qualifications, expertise, and experience, independent directors may effectively influence the board's decisions and ultimately add value to the organisation. Therefore, independent directors may provide external resources that are critical to the organisation's success, such as legitimacy, advice, and counsel.

Moreover, board size has a significant positive association with OSS and FSS. However, it has a significant negative relationship with the breadth of outreach. This finding supports the view of Hartarska and Mersland (2012) that board effectiveness will increase if the board size is maintained at up to eight or nine members, but board effectiveness will decrease beyond nine members. Hence, the ideal board size of eight to nine members is only marginally bigger than the sampled boards' size of eight members. This outcome is unique, given that there is no significant linear impact on panel size (Bassem, 2009; Hartarska, 2005; Mersland \& Strøm, 2009a). Regardless, this study's result is in line with the findings of established corporate governance studies (Fama \& Jensen, 1983; Herdhayinta, 2014; Jensen \& Meckling, 1976; Mori \& Mersland, 2014; Rashid, 2011; Rashid et al., 2010).

Furthermore, CEO duality has significant positive relationships with MFIs' performance in terms of operating and monetary sustainability as well as return on assets. Conversely, CEO duality has significant inverse relationships with the breadth and depth of outreach. These results imply that CEO duality does capture microfinance sustainability fully; however, it is a concern with the outreach to the poor. A number of propositions in the existing literature also support this study's results. Also, these results are consistent with the governance literature on banks and non-profit organisations (e.g., Hideto Dato et al., 2019; Thrikawala et al., 2016). For the MFIs in the sample, the board chairmen play a monitoring role and the CEOs assume the implementation responsibility. This result is similar to the studies of Bassem (2009), Hartarska (2005), Mersland and Strøm (2009), and Mersland et al. (2011), which found a linear impact of CEO duality.

This finding is also in line with the view of Jensen and Meckling (1976) and Shleifer and Vishny (1997) that CEO duality is vital for improving traditional values and enhancing firm performance. Further, this finding partially supports the proposition of stewardship theory that a motivated agent maximises and protects owners' wealth (Davis et al., 1997). However, the proposition of agency theory is rejected because it claims that owners' interest may differ from the manager's interest (Dey, 2008). Hence, this study accepts the proposition of stewardship theory but rejects the proposition of agency theory. 


\section{Conclusion}

This study has examined the role and effect of board independence in connection with microfinance's double bottom line performance in Bangladesh. This research has drawn some insights from corporate governance and microfinance literature. It has considered MFIs' dual missions, i.e. institutional sustainability and outreach to the poor, as the dependent variables.

The findings of this study suggest that board independence and other attributes of the board have significant positive impacts on microfinance sustainability. Nevertheless, the same variables have inverse effects on outreach to the poor. These findings partially support the view of agency theory, stakeholder theory, and resource dependence theory that independent directors always work for the betterment of the organisations they serve. In the context of Bangladesh, due to the high level of insider ownership and close relationships between family owners and outside directors, there is a relational contracting system whereby outside directors work collaboratively with owners who also have positions on the board and at the management level. Therefore, agency theory's proposition that independent directors work for the betterment of shareholders' interest is questionable in this instance.

Nevertheless, this study recognises that the board (in terms of board size and CEO duality) enhances MFIs' performance in Bangladesh. It also recognises that the existing literature endorses the notion that MFIs' competence influences microfinance governance mechanisms. Consequently, MFIs in Bangladesh, which have high proportions of insiders involved in the decision-making process, are adversely affected in terms of their operational and financial performance. This study argues that although MFIs' performance may improve if the board size is increased up to nine members, their performance may also decrease as the number of decision-makers increases. This argument suggests that board size plays a significant positive role in influencing MFIs' double bottom line performance. Any involvement in institutional malpractice amongst the board members may hurt the business. As many microfinance practitioners claim, supervisory bodies should consider the structure of the Anglo-American model of CEO dualism as it may augment MFIs' efficiency. The findings also partially support the proposition of stewardship theory that a motivated agent maximises and protects the owners' wealth. Conversely, the findings reject the proposition of agency theory that owners and managers may have different interests.

These outcomes demonstrate that many MFIs in Bangladesh have generally established their internal governance effectively. Improvements may be attained by separating executive positions from the board chair and minimising the involvement of donors and insiders on the board. Other measures that may help include empowering clients and extending the board size to a maximum of nine members. Future studies may expand on this study's approach and 
create a measure that also accounts for the dimension relating to MFIs' outreach to the poor. Further investigations may also seek insight into how MFIs' effectiveness affects the mechanisms of outside governance, such as international relations and regulations. MFIs' management must consider the welfare of customers and the profitability of their institution; thus, directors are responsible for several duties. Moreover, board members are a significant instrument of governance. Top-level managers have significant positive effects on institutional sustainability and the breadth of outreach performance. This study suggests that further research should be done on managerial compensation and performance indicators, with a more in-depth dataset.

This study is not without limitations. The data were mainly collected from MFIs' annual reports in Bangladesh. As a developing country, the accounting standards adopted by the Bangladeshi MFIs to prepare their annual reports may not result in a true representation of the organisations' state of affairs or performance. Furthermore, the data were collected from a large number of time-invariant observations of different microfinance entities; hence, similar information might be repeatedly used and redeployed in this study's analyses. Besides, MFIs may have different performance results due to their locations and management practices (including managing talents), and such results were not considered in this study.

\section{References}

Ahmad, S., \& Omar, R. (2016). Basic corporate governance models: A systematic review. International Journal of Law and Management, 58(1), 73-107. http://dx.doi.org/10.1108/IJLMA-10-2014-0057

Ahmed, S. (2009). Microfinance institutions in Bangladesh: Achievements and challenges. Managerial Finance, 35(12), 999-1010. https://doi.org/10.1108/03074350911000052

Akingunola, R. O., Adekunle, O. A., \& Adedipe, O. A. (2013). Corporate governance and bank's performance in Nigeria (Post-bank's consolidation). European Journal of Business and Social Sciences, 2(8), 89-111.

Al Farooque, O., Van Zijl, T., Dunstan, K., \& Karim, A. W. (2007). Corporate governance in Bangladesh: Link between ownership and financial performance. Corporate Governance: An International Review, 15(6), 1453-1468. https:// doi.org/10.1111/j.1467-8683.2007.00657.x

Anand, S. (2012). Sarbanes-Oxley Act. In Governance, Risk, and Compliance Handbook: Technology, Finance, Environmental, and International Guidance and Best Practices. https://doi.org/10.1002/9781118269213.ch67

Balachandran, B., \& Faff, R. (2015). Corporate governance, firm value and risk: Past, present, and future. Pacific-Basin Finance Journal, 35(2015), 1-12. http://dx.doi.org/10.1016/j.pacfin.2015.07.002

Balc, L. B., Ilies, R., Cioban, B., \& Cuza, B. (2013). Corporate governance: Conceptual approaches. Managerial Challenges of the Contemporary Society, 5, 14-17. https:// search.proquest.com/docview/1519306094?accountid=40355

Baltagi, B. H. (2008). Econometric Analysis of Panel Data. Econometric Theory, 13(5). https://doi.org/10.1017/S0266466600006150 
Bassem, B. S. (2009). Governance and performance of microfinance institutions in Mediterranean countries. Journal of Business Economics and Management, 10(1), 31-43. https:// doi.org/10.3846/1611-1699.2009.10.31-43

Bauer, R., Frijns, B., Otten, R., \& Tourani-rad, A. (2008). The impact of corporate governance on corporate performance: Evidence from Japan. Pacific-Basin Finance Journal, 16(2008), 236-251. https://doi.org/10.1016/i.pacfin.2007.05.001

Beisland, L. A., Mersland, R., \& Strøm, R. Ø. (2015). Audit Quality and Corporate Governance: Evidence from the Microfinance Industry. International Journal of Auditing, 19(3), 218-237. https://doi.org/10.1111/ijau.12041

Biswas, P. K. (2015). Corporate governance reforms in emerging countries: A case study of Bangladesh. International Journal of Disclosure and Governance, 12(1), 1-28. https://doi.org/10.1057/jdg.2013.31

Breitung, J., \& Das, S. (2005). Panel unit root tests under cross-sectional dependence. Statistica Neerlandica, 59(4), 414-433. https://doi.org/doi.org/10.1111/j.1467-9574.2005.00299.x

Brennan, N. M., \& Solomon, J. (2008). Corporate governance, accountability and mechanisms of accountability: An overview. Accounting, Auditing $\mathcal{E}$ Accountability Journal, 21(7), 885906. https://doi.org/10.1108/09513570810907401

Chen, S., \& Huang, Y. S. (2014). Corporate governance in emerging markets : An introduction. International Review of Economics and Finance, 32(2014), 1-2. http://dx.doi.org/10.1016/j.iref.2014.01.003

Cheung, Y., Connelly, J. T., Jiang, P., \& Limpaphayom, P. (2011). Does Corporate Governance Predict Future Performance? Evidence from Hong Kong. Financial Management, 40(1), 159-197. https://doi.org/10.1111/j.1755-053X.2010.01138.x

Christopher, J. (2010). Corporate governance-A multi-theoretical approach to recognizing the wider influencing forces impacting on organizations. Critical Perspectives on Accounting, 21(8), 683-695. https://doi.org/10.1016/j.cpa.2010.05.002

Copestake, J., Johnson, S., Cabello, M., Goodwin-Groen, R., Gravesteijn, R., Humberstone, J., Nino-Zarazua, M., \& Titus, M. (2016). Towards a plural history of microfinance. Canadian $\begin{array}{llll}\text { Journal of Development } & \text { Studies, }\end{array}$ https://doi.org/10.1080/02255189.2016.1197102

Creswell, J. W. (2013). Research Design: Qualitative, Quantitative, and Mixed Methods Approaches. In Research design Qualitative quantitative and mixed methods approaches. https:// doi.org/10.1007/s13398-014-0173-7.2

Cull, R., Demirgüç-Kunt, A., \& Morduch, J. (2009). Microfinance Tradeoffs: Regulation, Competition, and Financing (No. 5086; WPS5086). http:// documents.worldbank.org/curated/en/846571468339264494/Microfinancetradeoffs-regulation-competition-and-financing

Cull, R., Demirgüç-Kunt, A., \& Morduch, J. (2011). Does Regulatory Supervision Curtail Microfinance Profitability and Outreach? World Development, 39(6), 949-965. https://doi.org/10.1016/j.worlddev.2009.10.016

Cull, R., Demirgüç-Kunt, A., \& Morduch, J. (2014). Banks and Microbanks. Journal of Financial Services Research, 46(1), 1-53. https:// doi.org/10.1007/s10693-013-0177-z

Das, A., \& Ghosh, S. (2004). Corporate Governance in Banking System: An Empirical Investigation. Economic and Political Weekly, 39(12), 1263-1266. https:// doi.org/10.1016/j.jbankfin.2008.05.008

Davis, G. F. (2005). New directions in corporate governance. Annual Review of Sociology, 31(1), 143-162. https:// doi.org/10.1146/annurev.soc.31.041304.122249

Davis, J. H., Schoorman, F. D., \& Donaldson, L. (1997). Toward a stewardship theory of management. Academy of Management Review, 22(1), 20-47. https://doi.org/10.5465/amr.1997.9707180258 
Devi, P. S., \& Shaikh, M. A. (2017). Risk management practices of select microfinance institutions in Telangana State, India. International Journal of Economics and Management Systems, 2(1), 17-26. http:// www.iaras.org/iaras/journals/ijems

Dey, A. (2008). Corporate governance and agency conflicts. Journal of Accounting Research, 46(5), 1143-1181. https:// doi.org/10.1111/j.1475-679X.2008.00301.x

Di Benedetta, P. Lieberman, I. W., \& Ard, L. (2015). Corporate Governance in Microfinance Institutions. In Office of the Publisher, The World Bank. International Bank for Reconstruction and Development/The World Bank 1818 H Street NW Washington DC 20433.

https://openknowledge.worldbank.org/bitstream/handle/10986/22059/Corporate0go ve0finance0institutions.pdf?sequence $=1$

Donaldson, L. (1990). The ethereal hand: Organizational economics and management theory. Academy of Management Review, 369-381. https:// doi.org/10.5465/amr.1990.4308806

Donaldson, L., \& Davis, J. H. (1991). Stewardship theory or agency theory: CEO governance and shareholder returns. Australian Journal of Management, 16(1), 49-64. https:// doi.org/10.1177/031289629101600103

Drees, J. M., \& Heugens, P. (2013). Synthesizing and extending resource dependence theory: A meta-analysis. Journal of Management, 39(6), 1666-1698. https://doi.org/10.1177/0149206312471391

Eisenhardt, K. M. (1989). Agency theory: An assessment and review. The Academy of Management Review, 14(1), 57-74. https:/ / doi.org/10.5465/amr.1989.4279003

Fama, E. F., \& Jensen, M. C. (1983). Separation of Ownership and Control. The Journal of Law and Economics, 26(2), 301. https://doi.org/10.1086/467037

Freeman, R. E. (2010). Strategic Management: A Stakeholder Approach. In Cambridge University Press,. Cambridge University Press. https://doi.org/10.2139/ssrn.263511

Freeman, R. E., \& Evan, W. M. (1990). Corporate governance: A stakeholder interpretation. The Journal of Behavioral Economics, 19(4), 337-359. https://doi.org/10.1016/0090$\underline{5720(90) 90022-Y}$

Galema, R., Lensink, R., \& Mersland, R. (2012). Governance and Microfinance Institutions. In Research Handbook on International Banking and Governance (pp. 1-24). https://uia.brage.unit.no/uia-

xmlui/bitstream/handle/11250/2429825/Governance+and+Microfinance+Institutions+ official+version.docx? sequence $=2$

Greene, W. H. (2003). Econometric Analysis. New York: Pearson Education, Inc.

Gujarati, D. N. (2004). Basic Econometric. In The McGraw-Hill. https:// doi.org/10.1126/science.1186874

Halouani, N., \& Boujelbène, Y. (2015). External governance and dual mission in the African MFIs. Strategic Change, 24(3), 243-265. https:// doi.org/10.1002/jsc.2007

Hartarska, V. (2005). Governance and performance of microfinance institutions in Central and Eastern Europe and the Newly Independent States. World Development, 33(10), 1627-1643. https://doi.org/10.1016/j.worlddev.2005.06.001

Hartarska, V., \& Mersland, R. (2012). Which Governance Mechanisms Promote Efficiency in Reaching Poor Clients? Evidence from Rated Microfinance Institutions. European Financial Management, 18(2), 218-239. https:// doi.org/10.1111/j.1468-036X.2009.00524.x

Hartarska, V., Shen, X., \& Mersland, R. (2013). Scale economies and input price elasticities in microfinance institutions. Journal of Banking and Finance, 37(1), 118-131. http://dx.doi.org/10.1016/j.jbankfin.2012.08.00 
Hasan, T., Quayes, S., \& Khalily, B. (2019). Role of governance on performance of microfinance institutions in Bangladesh. Eurasian Economic Review, 9(1), 91-106. https:// doi.org/10.1007/s40822-018-0102-8

Herdhayinta, H. (2014). The Influence of Board Diversity on Financial Performance: An Empirical Study of Asia-Pacific Companies. University of Agder. https://pdfs.semanticscholar.org/9075/f7669d1b8fd3b27c6c66b7fde23c290459aa.pdf

Hideto Dato, M., Hudon, M., \& Mersland, R. (2019). Board Governance: Does Ownership Matter? Annals of Public and Cooperative Economics, 90(4), 1-24. https://doi.org/10.1111/apce.12262

Hill, C. W. L., \& Jones, T. M. (1992). Stakeholder-agency theory. Journal of Management Studies, 29(2), 131-154. https://doi.org/10.1111/j.1467-6486.1992.tb00657.x

Hossain, S. (2013). Does external stakeholder orientation in corporate governance influence in sustainability and outreach of microfinance institutions? Research Journal of Finance and Accounting, 4(14), 25-34. https://www.semanticscholar.org/paper/Does-ExternalStakeholder-Orientation-in-CorporateHossain/b0d2b1c231a75cca484f2968723fcf520fc5bde2

Hussain, M. D., Rahman, I. K. A., Hossin, M. S., \& Said, J. (2019). Board Leadership Structure and Microfinance Performance for Better Governance Practices in Bangladesh. International Journal of Business and Management Science, 9(2), 299-319. http://www.safaworld.org/ijbms/v9n2.htm

Im, J., \& Sun, S. L. (2015). Profits and outreach to the poor: The institutional logics of microfinance institutions. Asia Pacific Journal of Management, 32(1), 95-117. https:// doi.org/10.1007/s10490-014-9398-4

Jensen, M. C., \& Meckling, W. H. (1976). Theory of the Firm: Managerial Behavior, Agency Costs, and Ownership Structure. Journal of Financial Economics, 3(4), 305-360. https://doi.org/10.1016/0304-405X(76)90026-X

Jones, M. J. (2008). Internal Control, Accountability and Corporate Governance: Medieval and Modern Britain Compared. Accounting, Auditing and Accountability Journal, 21(7), 10521075. https:// doi.org/10.1108/09513570810907474

Kar, A. K. (2012). Does capital and financing structure have any relevance to the performance of microfinance institutions? International Review of Applied Economics, 26(3), 329-348. https:// doi.org/10.1080/02692171.2011.580267

Kar, A. K. (2013). Mission drift in microfinance: are the concerns really worrying? Recent crosscountry results. International Review of Applied Economics, 27(1), 44-60. https://doi.org/10.1080/02692171.2012.700701

Khatun, S. (2006). Bangladesh Microfinance Country Profile. In Credit and Development Forum (CDF) (January Issue).

Krause, R., Semadeni, M., \& Cannella, A. A. (2014). CEO Duality: A Review and Research Agenda. Journal of Management, 40(1), 256-286. https://doi.org/10.1177/0149206313503013

Kyereboah-Coleman, A., \& Osei, K. A. (2008). Outreach and profitability of microfinance institutions: the role of governance. Journal of Economic Studies, 35(3), 236-248. https://doi.org/10.1108/01443580810887797

Lai, P., \& Choi, O. (2014). Corporate Governance and Financial Performance of Bank in Asian Regions and Recommendations. Asian Journal of Finance and Accounting, 6(2), 377-406. https:// doi.org/10.5296/ajfa.v6i2.6429

Mersland, R., Randøy, T., \& Strøm, R. Ø. (2011). The impact of international influence on microbanks' performance: A global survey. International Business Review, 20(2), 163-176. https://doi.org/10.1016/j.ibusrev.2010.07.006 
Mersland, R., \& Strøm, R. Ø. (2009a). Performance and governance in microfinance institutions. Journal of Banking and Finance, 33(4), 662-669. https:// doi.org/10.1016/j.jbankfin.2008.11.009

Mersland, R., \& Strøm, R. Ø. (2009b). What explains governance structure in non-profit and for-profit microfinance institutions? Social Science Research Network (SSRN), 32(June), 125. http://ssrn.com/abstract $=1342427$

Mersland, R., \& Strøm, R. Ø. (2013). What Drives the Microfinance Lending Rate? In Midwest Finance Association 2013 Annual Meeting Paper (Issue September). http://dx.doi.org/10.2139/ssrn.2144618

Mersland, R., \& Strøm, R. Ø. (2014). Measuring Microfinance Performance. In Microfinance Institutions (pp. 1-21). Springer. https://doi.org/10.1057/9781137399663_2

Mia, M. A., \& Chandran, V. G. R. (2016). Measuring Financial and Social Outreach Productivity of Microfinance Institutions in Bangladesh. Social Indicators Research, 127(2), 505-527. https://doi.org/10.1007/s11205-015-0979-5

Mori, N., \& Mersland, R. (2014). Boards in microfinance institutions: How do stakeholders matter? Journal of Management and Governance, 18(1), 285-313. https://doi.org/10.1007/s10997-011-9191-4

Nasir, N. M., \& Ali, M. M. (2018). Corporate governance and financial distress: Malaysian perspective. Asian Journal of Accounting Perspectives, 11(1), 108-128. https://ajap.um.edu.my/article/view/13417

OECD. (2015). G20/OECD Principles of Corporate Governance (pp. 1-60). OECD Publishing, Paris. http://dx.doi.org/10.1787/9789264236882-en

Pfeffer, J., \& Salancik, G. R. (2003). The External Control of Organizations: A Resource Dependence Perspective (2nd ed). Stanford University Press.

Pugliese, A., Minichilli, A., \& Zattoni, A. (2014). Integrating agency and resource dependence theory: Firm profitability, industry regulation, and board task performance. Journal of Business Research, 67(6), 1189-1200. http://dx.doi.org/10.1016/j.jbusres.2013.05.003

Quayes, S., \& Khalily, M. a B. (2013). Efficiency of Microfinance Institutions in Bangladesh (No. 19; Issue 19). http://socialprotection.gov.bd/wp-content/uploads/2017/03/InMworkingpaper19-1.pdf

Rahman, I. K. A., Hussain, M. D., \& Hossin, M. S. (2019). Microfinance governance: A multitheoretical approach for ascertaining the wider stakeholder influencing forces. Asian Academy of Management Journal, 24(1), 203-216. https://doi.org/10.21315/aamj2019.24.s1.14

Rashid, A. (2010). CEO duality and firm performance: Evidence from a developing country. Corporate Ownership \& Control, 8(1), 161-175. www.virtusinterpress.org

Rashid, A. (2011). Board leadership structure and firm performance: An examination of resource dependence role. Corporate Board: Role, Duties \& Composition, 7(1), 1-23. www.virtusinterpress.org

Rashid, A. (2013). CEO duality and agency cost: Evidence from Bangladesh. Journal of Management and Governance, 17(4), 989-1008. https:/ / doi.org/10.1007/s10997-012-9213-x

Rashid, A. (2015a). Managerial ownership and agency cost: Evidence from Bangladesh. Journal of Business Ethics, 137(3), 609-621. https://doi.org/10.1007/s10551-015-2570-z

Rashid, A. (2015b). Revisiting agency theory: Evidence of board independence and agency cost from Bangladesh. Journal of Business Ethics, 130, 181-198. https://doi.org/10.1007/s10551014-2211-y

Rashid, A. (2015c). The influence of stakeholder power on corporate social responsibility: Evidence from a relationship-based economy. Social Responsibility Journal, 11(2), 270-289. https://doi.org/10.1108/SRJ-09-2013-0109 
Rashid, A., Zoysa, A. De, Lodh, S., \& Rudkin, K. (2010). Board composition and firm performance: Evidence from Bangladesh. Australasian Accounting Business and Finance Journal, 4(1), 76-95. http://ro.uow.edu.au/aabfj/vol4/iss1/5

Rashid, A., Zoysa, A. De, \& Rudkin, K. (2007). Corporate governance in Bangladesh: An overview. Presented in the 19th Asian-Pacific Conference on International Accounting Issues, 11-13 Nov 2007, Kuala Lumpur, Malaysia., 34-39.

Rost, K., Inauen, E., Osterloh, M., \& Frey, B. S. (2010). The corporate governance of Benedictine abbeys: What can stock corporations learn from monasteries? Journal of Management History, 16(1), 90-115. https:// doi.org/10.1108/17511341011008331

Schneider, A., \& Scherer, A. G. (2015). Corporate Governance in a Risk Society. Journal of Business Ethics, 126, 309-323. https:// doi.org/10.1007/s10551-013-1943-4

Shleifer, A., \& Vishny, R. W. (1997). A survey of corporate governance. The Journal of Finance, 52(2), 737-783. https://doi.org/10.1111/j.1540-6261.1997.tb04820.x

Siti-Nabiha, A. K., Azhar, Z., Isa, S. M., \& Siti-Nazariah, A. Z. (2018a). Measuring social performance: Reconciling the tension between commercial and social logics. International Journal of Social Economics, 45(1), 205-222. https://doi.org/10.1108/IJSE-08-2016-0216

Siti-Nabiha, A. K., Azhar, Z., \& Ali-Mokhtar, M. A. (2018b). Management control for microfinance: An examination of the belief system of a Malaysian microfinance provider. Asian Academy of Management Journal of Accounting and Finance, 14(1), 185-208. https:// doi.org/10.21315/aamjaf2018.14.1.8

Stein, M. J. (2008). Beyond the boardroom: Governmental perspectives on corporate governance. Accounting, Auditing and Accountability Journal, 21(7), 1001-1025. https://doi.org/10.1108/09513570810907456

Sundaram, A. K., \& Inkpen, A. C. (2004). Stakeholder theory and "The corporate objective revisited": A reply. Organization Science, 15(3), 370-371. https://doi.org/10.1287/orsc.1040.0067

Terjesen, S., Couto, E. B., \& Francisco, P. M. (2016). Does the presence of independent and female directors impact firm performance? A multi-country study of board diversity. Journal of Management and Governance, 20(3), 447-483. https://doi.org/10.1007/s10997014-9307-8

Thrikawala, S., Locke, S., \& Reddy, K. (2016). Board structure-performance relationship in microfinance institutions (MFIs) in an emerging economy. Corporate Governance, 16(5), 815-830. https://doi.org/10.1108/CG-12-2015-0166

Uddin, S., \& Choudhury, J. (2008). Rationality, traditionalism and the state of corporate governance mechanisms: Illustrations from a less-developed country. Accounting, Auditing accountability Journal, 21(7), 1026-1051. https://doi.org/10.1108/09513570810907465

Umor, S., Zakaria, Z., \& Sulaiman, N. A. (2020). Effectiveness of follow-up on performance auditing issues in practice: A governance network perspective. Asian Journal of Accounting Perspectives, 13(1), 1-25. https://doi.org/10.22452/ajap.vol13no1.1

Wooldridge, J. M. (2010). Econometric Analysis of Cross Section and Panel Data. In MIT Press Books (Vol. 1). https:// mitpress.mit.edu/books/econometric-analysis-cross-section-andpanel-data-second-edition

Zabri, S. M., Ahmad, K., \& Wah, K. K. (2016). Corporate governance practices and firm performance: Evidence from top 100 public listed companies in Malaysia. In the 7th International Economics \& Business Management Conference, 5th \& 6th October 2015, 35(2016), 287-296. https:// doi.org/10.1016/S2212-5671(16)00036-8

Zagorchev, A., \& Gao, L. (2015). Corporate governance and performance of financial institutions. Journal of Economics and Business, 82, 17-41. http://dx.doi.org/10.1016/j.jeconbus.2015.04.004 